JOURNAL OF SECURITY AND SUSTAINABILITY ISSUES

ISSN 2029-7017 print/ISSN 2029-7025 online

2020 June Volume 9 Number 4

https://doi.org/10.9770/jssi.2020.9.4(29)

Scopus

\title{
MIGRATION RISK MANAGEMENT AS A FACTOR OF NATIONAL SECURITY
}

\author{
Oleg Reznik ${ }^{1}$, Oleksandr Muzychuk², Oleksandr Yunin ${ }^{3}$, Svetlana Kaliuzhna $^{4}$, Oleksandr Dubenko ${ }^{5}$ \\ ${ }^{1 *}$ Sumy State University, 2 Rimsky-Korsakova Street, Sumy, 40000, Ukraine \\ ${ }^{2}$ Kharkiv National University of Internal Affairs, Lviv Landau avenue, 27, Kharkiv, 61000, Ukraine \\ ${ }^{3}$ Dnipropetrovsk State University of Internal Affairs, Ave. Gagarina, 26, 49005, Dnipro, Ukraine \\ ${ }^{4}$ Sumy National Agrarian University, Gerasim Kondratieva Street, 160, Sumy, 40000, Ukraine \\ ${ }^{5}$ Odessa State University of Internal Affairs, Uspenskaya street, 1, Odessa, 65000, Ukraine \\ E-mail: 1"reznikoleg@yahoo.com (Corresponding author)
}

Received 18 October 2019; accepted 10 May 2020; published 30 June 2020

\begin{abstract}
The article theoretically substantiates the methodological approaches and tools of comprehensive statistical analysis of labor migration, based on the principles of systematic research from the standpoint of integrity and integration of processes. This, in turn, allowed to identify the main elements and features that characterize labor migration, as the object of statistical research, as well as to carry out an objective analysis of the condition and development of this phenomenon at both national and regional levels. The role of statistical analysis of labor migration in the management system based on the analysis of the experience of developed countries was also determined. A conceptual approach in the field of state regulation of labor migration was proposed, which is based on the application of a systematic approach and compliance with its basic principles. The place of statistical assessment and monitoring of labor migration was established as one of the main tools for regulating the number of labor migrants from the standpoint of systematics. The results of the assessment of the procedures for acquiring citizenship and issuing permits for foreigners in Ukraine have been analyzed. Moreover, practical recommendations were provided based on a statistical analysis of the procedure for acquiring citizenship and issuing permits to foreigners in accordance with the principles of human rights and non-discrimination. Peculiarities of legal regulation regarding the migration processes in Ukraine were studied. The identified shortcomings and "gaps" in the legal field of Ukraine allow to form practical recommendations on the legal regulation of migration processes in accordance with the basic principles of European integration.
\end{abstract}

Keywords: national security; migration processes; social risks; migration risks; immigration compensators

Reference to this paper should be made as follows: Reznik, O., Muzychuk, O., Yunin, O., Kaliuzhna, S., Dubenko, O. 2020. migration risk management as a factor of national security, Journal of Security and Sustainability Issues 9(4), 1471-1482.

https://doi.org/10.9770/jssi.2020.9.4(29)

JEL Classifications: F35; F42

\section{Introduction}

The development peculiarity of modern society is that any social activity is characterized by dynamics of all processes and their uncertainty. Thus, risk is a sign of any purposeful activity of a social subject, which in turn directs efforts to reduce the uncertainty of its results.

The structure of the social impression consists of the central nucleus and the peripheral system. The central core is connected with the collective memory and history of the group, it is stable and performs the function of producing social impression. The peripheral system ensures the integration of the individual experience of each member of the group, maintains its heterogeneity, it is also characterized by changes, certain contradictions, adaptability to reality; the system allows content differentiation, however, it protects the central core from any external influences. 
Taking into account the objectivity of social life, it is necessary to recognize the attributiveness of risk for the progressive development of society. Risk, in most cases, has a social nature, as it is produced by social subjects, and its actualization affects their main characteristics and interaction. Therefore, the concept of social risk gradually acquires the status of a general scientific category, because of this there is an expansion of the range of theoretical problems that are associated with the need to study its latest aspects. There is a lot attention in economic literature to wide range of risks to economic development (e.g. Lincényi, Čársky, 2020; Tvaronavičienè, Ślusarczyk, 2019; Plèta et al., 2020; Chehabeddine, Tvaronavičienè, 2020)

Migration risks, in terms of security, are related to the impact of migration processes on the level of crime, as well as to the objective and subjective security of migrant workers and residents of host societies. It should be noted that the relevance of the study in theoretical terms is confirmed by the shortage of sound theoretical studies and tools for empirical research of migration risks that arise during the working process and intercultural interaction of migrants abroad.

In the framework of Ukraine-EU cooperation, as a result of the Agreement concluded in 2014, one of the main goals was to strengthen cooperation in the field of justice, freedom, and security in order to ensure the rule of law and respect for human rights and fundamental freedoms (Association Agreement, 2014). Based on the requirements defined by the Agreement, the priority direction was recognized to bring the norms of Ukrainian legislation to the standards of European law, including human rights standards. The provisions of the Agreement establish that the national legal regime for the stay of foreigners in the territory of the country should provide for the granting of rights, freedoms, and duties to such persons, which belong to Ukrainian citizens as well, of course, with the exception of certain restrictions. Confirmation of this is the norm of the Constitution of Ukraine in 1996. According to Art. 26, foreigners and stateless persons who are legally in Ukraine enjoy the same rights and freedoms and also bear the same duties as Ukrainian citizens, with the exceptions established by the Constitution, laws or international treaties of Ukraine (Constitution of Ukraine, 1996).

International cooperation results in an influx of foreign citizens into other countries. At the same time, there are not only foreigners on the territory of the state but also stateless persons. Moreover, with the increase in the number of these persons temporarily or permanently located in the country, an increase in the number of offenses is inevitable. In this context, offenses are committed both directly by foreign citizens or stateless persons and in relation to them. For example, cases of illegal migrants staying on the territory of Ukraine are frequent. Therefore, in view of the foregoing, the introduction of effective mechanisms to counter such negative phenomena by bringing individuals to liability requires important attention. The presence of an appropriate regulatory framework allows not only to apply appropriate sanctions for the results of an already committed offense but also to prevent its commission.

\section{Literature Survey}

In the framework of the subject under study, important attention is required to define the concepts of "foreigners" and "stateless persons". To this end, it is advisable to turn to the approaches of scientists to the interpretation of these categories. Levenets (2017) defines the concept of "foreigner" through characteristic features, namely: 1) it denotes persons who do not own Ukrainian citizenship; 2) these persons are citizens or nationals of other states and can prove this by relevant documents; 3 ) these persons permanently or temporarily reside on the territory of the Ukrainian state, and therefore are in legal relations with the relevant authorities; 4) these persons continue to be in legal and political relations with the state of their citizenship and therefore are in dual subordination.

According to Tymchyk (2014), the concept of "foreign citizen" is separable and is identical to the concept of "stateless person". The scientist substantiates his position by the fact that in fact the concept of "foreigner" is identified with the concept of "foreign citizen".

Vasylchenko (2014), depending on the degree of proximity of a person to the state and the features of the legal 
relationship between them, considers it as separate categories of citizens (nationals), foreigners, and stateless persons.

In turn, Hrabylnikov (2015) notes that the concept of "foreigners" is broadly complex since it covers all citizens of foreign states, stateless persons, refugees, foreign Ukrainian, and immigrants in Ukraine, permanently or temporarily residing or staying in Ukraine. At the same time, the scientist comes to the conclusion that all the listed individuals are united by a generic attribute: they came from other lands - territories of other states. However, the important differences, in this case, are the following: 1) different constitutional status; 2) the different legal regime of stay in Ukraine, which is explained by the various interests of the stay with the legal possibilities to satisfy them.

Similarly, the position of Turetska (2018) also concludes that the concept of "foreigner" includes such categories of legal entities as "foreign citizen", "stateless person", and "refugee".

Thus, the scientific approaches to the definition of the essence of the concepts of "foreigners" and "stateless persons" can be combined into two groups: 1) some scientists consider them as separate categories, 2) others, on the contrary, include the concept of "stateless persons" in the scope of the concept of "foreigners". In our opinion, it is not entirely possible to agree with the second approach since an important distinguishing feature is the different legal status of these persons, based on the presence of citizenship or lack thereof. Therefore, the two concepts studied should not be identified or confused.

It is also important to focus on the fact that the concept of "stateless person" has been interpreted not only at the doctrinal level but also in international regulatory documents. Among international documents relating to the determination of the status of stateless persons, an important place belongs to the Convention relating to the Status of Stateless Persons 1965 and the Convention on the Reduction of Statelessness of 1961. In particular, in Art. 1 Convention Relating to the Status of Stateless Persons, a stateless person is defined as a person that no state considers a citizen based on their own laws (Convention Relating to the Status of Stateless Persons, 1954). Thus, a lack of citizenship in any country is the so-called "legal anomaly" that can prevent interested persons from gaining access to basic human rights of a civil, political, economic, social, and cultural nature (Statelessness in the EU, 2016). Convention on the Reduction of Statelessness is the leading international document that sets the rules for conferring and non-exclusion of citizenship to prevent statelessness (Convention on the Reduction of Statelessness, 1961).

\section{Methods}

The study of the characteristics of the liability of foreigners and stateless persons as a guarantee of ensuring the national security of the state, in particular, types of legal liability, the legal framework, under which bringing these persons to this or that kind of liability, the nature and types of sanctions/penalties, depending on the type of legal liability, etc., are carried out using dialectical, formal, legal, epistemological, and systemic-structural methods.

Using the dialectical method, the essence of the concepts of "foreigner" and "stateless person" is defined.

The formal legal method was used to disclose the content and interpretation of the provisions of certain regulatory legal acts of the current Ukrainian legislation, the norms of which establish the specifics of the legal liability of foreigners and stateless persons, including determining the competence of which state bodies includes taking a decision about instituting administrative action against foreigners and stateless persons, what are the grounds for attracting foreigners and stateless persons to a particular type of legal liability, what types of sanctions/punishment can be applied as a result of the commission of an offense/crime, and so on.

The epistemological method of research made it possible to clarify the features of certain types of legal liability of foreigners and stateless persons, to identify and characterize the barriers to attracting one or another type of 
liability of such persons, to establish a measure of liability in the form of sanctions/punishments depending on the type of legal liability of foreigners and stateless persons.

Statistical assessment of migration processes requires the availability of information regarding the quantity of population, employment and unemployment, labor force, border statistics on migration of the working population.

Population censuses, current accounting, statistical reporting of the state employment service, sample surveys, public opinion polls and other sociological surveys are the sources of this information support. However, the current accounting of migration events is the main source of operational information on population migration in Ukraine. It is carried out by registering persons involved in migration processes, as well as those who register at a new place of residence. This procedure involves filling out statistical coupons in the arrival and departure address sheets.

International organizations, especially structures within the UN, regularly collect information, which further replenishes publicly available databases on the movement and contingents of migrants. In order to obtain valid and homogeneous statistics, relevant inquiries are sent to countries. Except for the questionnaire of Eurostat, the Council of Europe and the European Economic Commission, which has been sent to the countries of the region since 1993.

For various reasons, national statistical centers may not always be able to provide such information freely. Most often this is due to the lack of data on the required variables. Despite the objective reasons for which these statistics are not available, it should be emphasized that these data are needed not only for international organizations, but primarily for the users within the country.

\section{Results}

Migration processes are constantly changing, so census data is insufficient during the study of such a dynamic phenomenon. Continuous monitoring of indicators of the scale and direction of labor migration, as well as assessment of the levels of intensity of this process is possible only through sample surveys of the labour force. Survey data are the most effective way to obtain data on employment and movement, as they provide consistent and complete information on labor migration at the regional, national and interstate levels.

Despite the fact that sample surveys allow to obtain information about migration processes effectively, there is a range of other advantages over other types of observations. Sample surveys are the most flexible tool for collecting statistical information, as they allow, during the process of studying the economic activity of the population, to change and adapt the definition and detail of questions to the objective requirements. The universality of these surveys allows to provide static information regarding the movement of the working population to a wide range of users.

Scientifically based sampling allows to take into account almost all social groups of the population, all areas of economic activity and workers categories. Nowadays, the growing influence of demographic factors on the migration scope is evident in Western Europe and Russia, where low population growth and the aging of the nation are mostly compensated by immigrants. Thus, net immigration provides $56 \%$ of demographic growth in developed regions of the world, in particular in Western European countries - 89\%. Today in the countries that are the main recipients of foreign labor, the share of foreigners is $5-20 \%$ of the total population, or $10-25 \%$ of its economically active share of population (http://ec.europa.eu/eurostat/web/population-demography-migrationprojections).

Next, immigration compensators for 2000-2050 should be considered (Table 1). 
Table 1. Immigration compensators for the period 2000-2050, thousand people per $1 \mathrm{mln}$. residents every year

\begin{tabular}{|c|c|c|}
\hline Country & $\begin{array}{c}\text { Immigration required to support the working } \\
\text { population (15-64 years) }\end{array}$ & $\begin{array}{c}\text { Immigration required to maintain the ratio of people } \\
\text { over the age of 65 / people 15-64 years old }\end{array}$ \\
\hline Germany & 6,0 & 44,8 \\
\hline Italy & 6,5 & 39,8 \\
\hline France & 1,8 & 30,4 \\
\hline USA & 1,3 & 43,2 \\
\hline Japan & 5,1 & 85,6 \\
\hline Russia & 2,1 & 20,3 \\
\hline
\end{tabular}

Source: compiled by the author using the resource

http://ec.europa.eu/eurostat/web/population-demography-migration-projections

It should be noted that in the period up to 2050 the following countries will need the most compensatory net immigration: Germany (almost 45 thousand people per 1 million inhabitants annually), Italy (39.8 thousand), France (30.4 thousand), USA (43.2 thousand), Japan (82.6 thousand). Even Russia will need about 20.3 thousand foreigners per $1 \mathrm{mln}$. residents (Table 1).

It should also be noted that significant changes in the innovation and technological development of countries is due to the migration of highly qualified specialists. Due to the formation of the global scientific and educational space, there has been an increase in the international mobility of intellectual personnel in the context of the rapid development of international information and communication networks.

The virtualization of production processes is becoming increasingly important due to the development of the information economy, in which labor is involved into processes of the foreign countries without changing its physical location through online outsourcing tools (quasi-migration processes).

Today, online outsourcing is a worthy alternative to traditional forms of employment, representing a more flexible and fast hiring system through online platforms (for example, the Upwork platform (after the merger of freelance platforms Elance and oDesk in 2015), opening wider access to highly specialized workers, as well as implementing a 24-hour work schedule, and in general, introducing a new competition format in the global labor market. According to the Upwork online platform data, the number of registered freelancers on this platform in 2014 reached 10 million people and 4 million businesses, whose total revenue in 2014 was about $\$ 3.2$ billion. (https://www.upwork.com/ ).

Asian countries ( 80 million people) and European countries (78 million people) are the largest recipients of labor migration (Table 2).

Table 2. Number of international migrants by region, million people

\begin{tabular}{|c|c|c|c|c|c|c|}
\hline \multirow{2}{*}{ Region } & \multicolumn{2}{|c|}{ arrived } & \multicolumn{2}{c|}{ emigrated } & \multicolumn{2}{c|}{ balance } \\
\cline { 2 - 8 } & $\mathbf{2 0 0 0}$ & $\mathbf{2 0 1 7}$ & $\mathbf{2 0 0 0}$ & $\mathbf{2 0 1 7}$ & $\mathbf{2 0 0 0}$ & $\mathbf{2 0 1 7}$ \\
\hline Asia & 49,2 & 79,6 & 65,0 & 105,7 & $-15,8$ & $-26,1$ \\
\hline Europe & 56,3 & 77,9 & 49,6 & 61,2 & 6,7 & 16,7 \\
\hline North America & 40,4 & 57,7 & 3,2 & 4,4 & 37,2 & 53,3 \\
\hline Africa & 14,8 & 24,7 & 21,6 & 36,3 & $-6,8$ & $-11,6$ \\
\hline Latin America and the Caribbean countries & 6,6 & 9,5 & 24,8 & 37,7 & $-18,2$ & $-28,2$ \\
\hline Oceania & 5,4 & 8,4 & 1,2 & 1,9 & 4,2 & 6,5 \\
\hline
\end{tabular}

Source: compiled by the author using the resource

http://ec.europa.eu/eurostat/web/population-demography-migration-projections 
During the period from 2000 to 2017, Asia received the largest number of international migrants compared to any other region: about 30 million international migrants were involved, a net increase is about 1.8 million migrants per year. Despite the increasement in migration flows, the share of international migrants in Asia, Africa and Latin America does not exceed 2\% of the total population of the region, while in Europe, North America and Oceania the share of international migrants makes at least $10 \%$ of the total population. (http://ec.europa.eu/ eurostat/web/population-demography-migration-projections).

In the process of analyzing the structure of international migrants in terms of their origin, it should be noted that in 2017, out of 258 million international migrants in the world, 106 million were born in Asia. Europe ranked second in the origin of migrants (61 million people), followed by Latin America, the Caribbean (38 million people) and Africa (36 million people). By country of origin, the largest number of migrants in the world was from India (17 million people), Mexico (13 million people), the Russian Federation (11 million people), China (10 million people), Bangladesh (7 million people), Syria (7 million people), Pakistan (6 million people) and Ukraine (6 million people).

The movement direction of migrants from different countries is gradually changing compared to the data of the beginning of the century. The largest increase in migration can be observed between Africa and North America, in the period from 2000 to 2017, the average annual growth rate of migrants from Africa to the United States and Canada was $4,9 \%$ or 1,5 million people per year. For comparison, in Asia, the growth in the number of migrants from Africa reached an average of $4.2 \%$ (http://ec.europa.eu/eurostat/web/population-demographymigration-projections ).

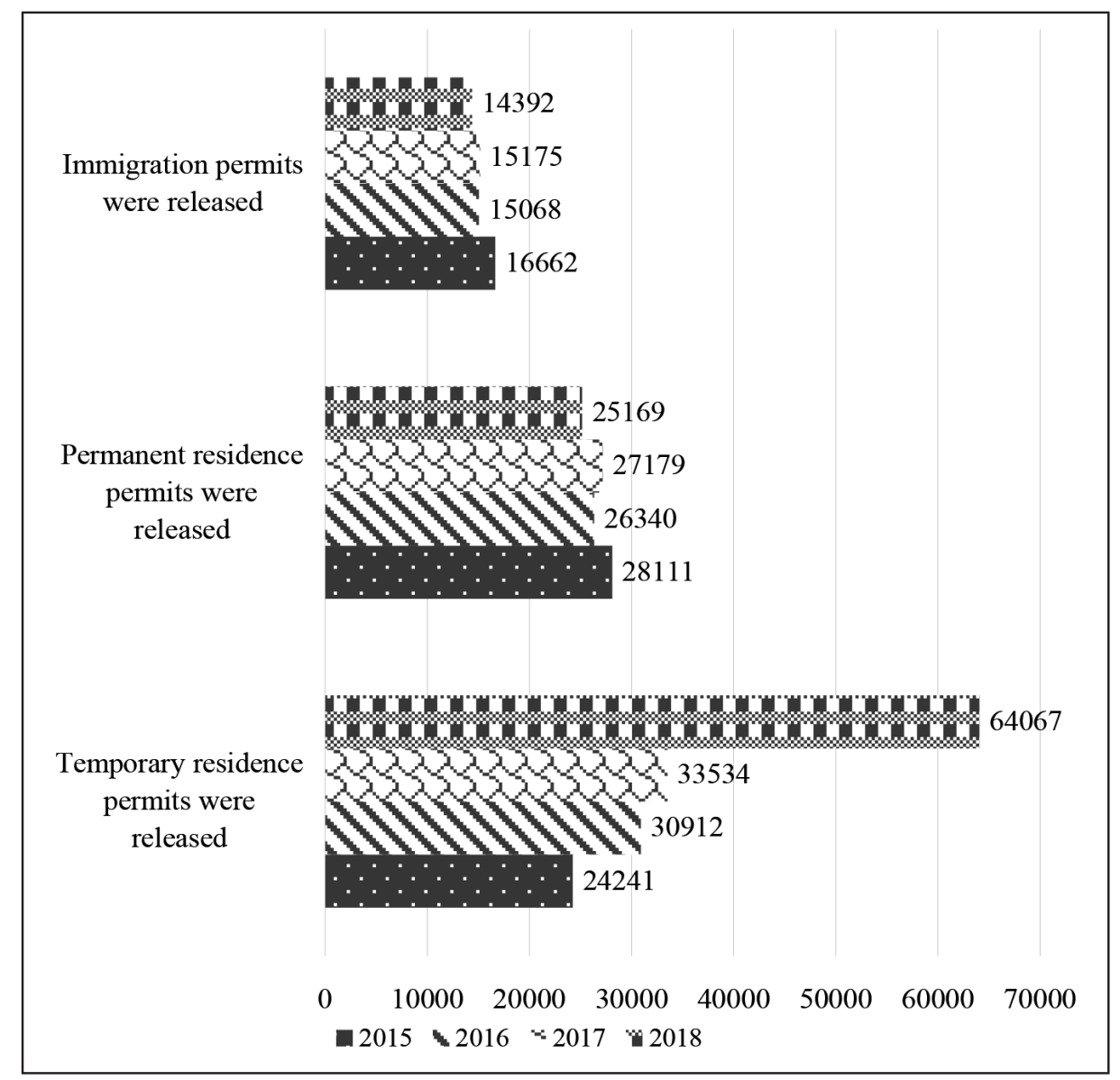

Figure 1. Registration of temporary and permanent residence permits and immigration permits in Ukraine, during the period from 2015 to 2018

(constructed using the resource: https://dmsu.qov.ua/divalnist/statistichni-dani/statistika-z-osnovnoi- diyalnosti.html ) 
However, the simplification of the employment process for the foreign workers was highly praised by relevant experts interviewed in the study. Moreover, statistics show that the number of temporary residence permits issued in Ukraine almost doubled in 2018 (64,000) compared to 2017 (33,5 thousand). It should be noted that the growth could also be affected by the adoption of a new Procedure for issuing a temporary residence permit, in which this procedure was reduced to 15 working days.

The statistics data allow us to conclude that legislative innovations did not increase the number of people who immigrated to Ukraine during 2018. Nevertheless, the number of permanent residence permits and immigration permits has decreased (Figure 1).

In addition, in the short term, changes in legislation did not affect the rate of immigration of foreign investors to Ukraine. Nowadays, in order to obtain an immigration permit and in the future - a permanent residence permit, foreigners need to invest into the Ukrainian economy the amount of at least 100 thousand dollars. During 2016, 12 people received immigration permits under this procedure, in 2017 - 13, and in 2018 - only 9 foreign investors.

Summarizing all the above, it should be noted that recent changes in legislation in the field of simplification of employment of foreign workers, along with other innovations have contributed to a significant increase in demand for temporary residence permits in Ukraine. However, changes in the procedure of acquiring citizenship by foreign servicemen did not have any significant effect. In general, the legislative changes did not affect the formation of the immigration quota, as well as the emission of immigration permits and permanent residence permits, which in turn is confirmed by the relatively constant low rates of these services during 2015-2018. This confirms that the priorities of Ukraine's state migration policy were to attract foreigners on a temporary basis, while the implementation of the new State Migration Policy Strategy remains important, which indicates the need to adjust immigration legislation to the economic and demographic policy, and the need to review the feasibility of forming an immigration quota.

Foreigners willing to acquire Ukrainian citizenship and obtain permanent and temporary residence permits face a number of certain bureaucratic barriers: difficulties in obtaining documents, communication with representatives of relevant authorities, queues, etc. The complexity of procedures related to the acquisition of citizenship in combination with low socio-economic indicators within the country have lead to a slight increase in the number of Ukrainian citizens from abroad.

The procedure for is more accessible to foreigners, which requires fewer documents and the involvement of only two structural SMS (State Migration Service) branches. During 2015-2017, every year about 4 thousand people acquired the citizenship of Ukraine by territorial origin, which is almost 4 times more than the number of those who were granted citizenship by the Decree of the President of Ukraine (Figure 2). 


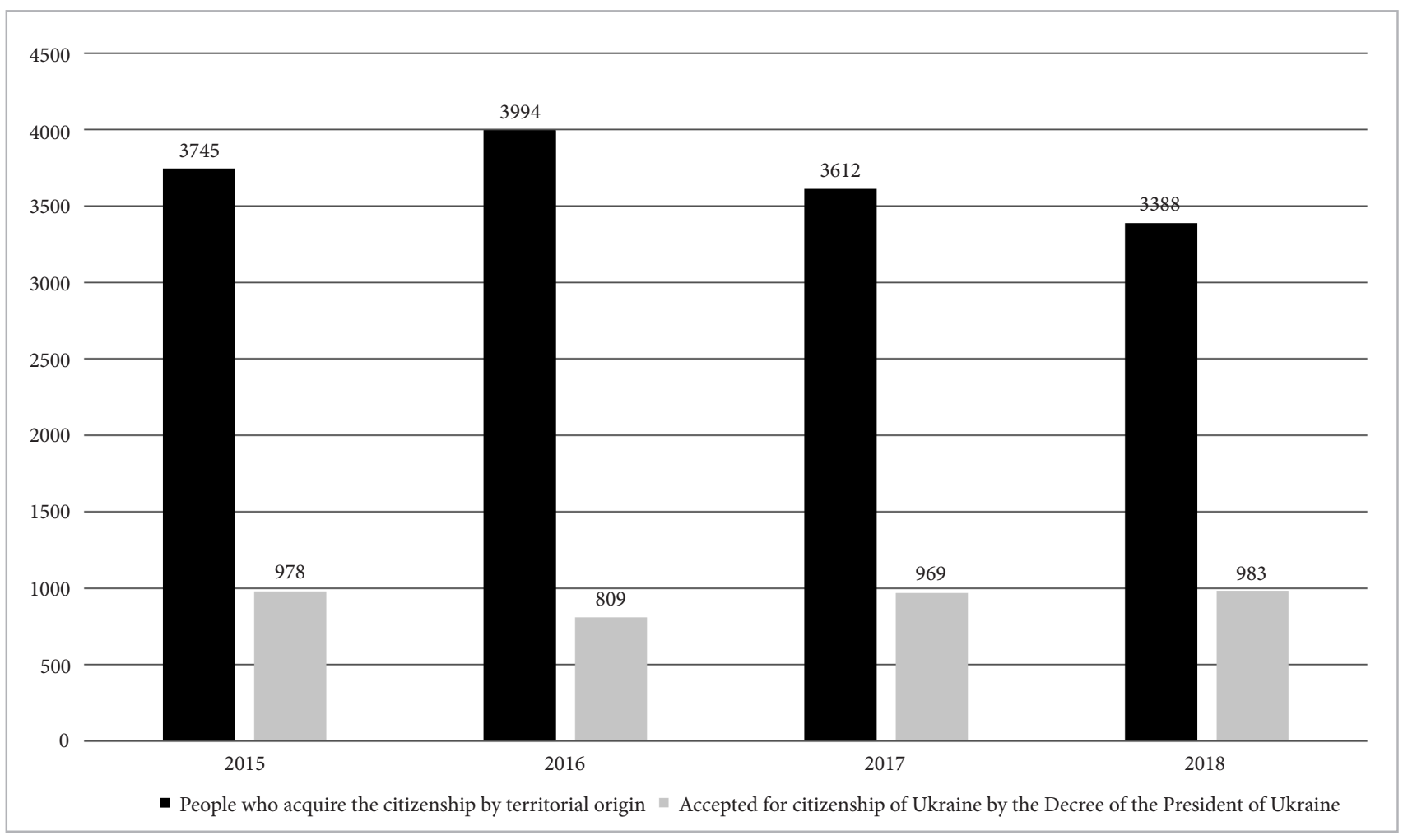

Figure 2. Acquisition of citizenship by territorial origin and as a result of admission to citizenship by decree of the President of Ukraine, 2015-2018, thousands of people (constructed using the resource: https://dmsu.qov.ua/divalnist/statistichni-dani/statistika-z-osnovnoi- diyalnosti.html )

Foreigners from countries in which a large share of the Ukrainian diaspora is concentrated, in particular people from the Russian Federation, Azerbaijan, Moldova, Armenia, Uzbekistan and Georgia, most often acquire Ukrainian citizenship by territorial origin (Table 3).

Table 3. Quantitative indicators of citizenship acquisition by territorial origin, and as a result of admission to citizenship of Ukraine, 2015-2017, thousand people

\begin{tabular}{|l|c|c|c|l|l|c|c|}
\hline \multicolumn{4}{|c|}{$\begin{array}{c}\text { Number of people who acquired Ukrainian } \\
\text { citizenship by territorial origin }\end{array}$} & \multicolumn{3}{c|}{$\begin{array}{c}\text { Number of persons who have been } \\
\text { granted Ukrainian citizenship }\end{array}$} \\
\hline \multicolumn{1}{|c|}{ Country of citizenship } & $\mathbf{2 0 1 5}$ & $\mathbf{2 0 1 6}$ & $\mathbf{2 0 1 7}$ & $\mathbf{2 0 1 5}$ & $\mathbf{2 0 1 6}$ & $\mathbf{2 0 1 7}$ \\
\hline Russian Federation & 1837 & 1835 & 1499 & Syrian Arab Republic & 107 & 98 & 155 \\
\hline Azerbaijan & 198 & 303 & 342 & Russian Federation & 128 & 131 & 139 \\
\hline Vietnam & 223 & 243 & 305 & Armenia & 116 & 64 & 98 \\
\hline Moldova & 383 & 326 & 280 & Afghanistan & 110 & 61 & 86 \\
\hline Armenia & 194 & 204 & 173 & Moldova & 68 & 43 & 55 \\
\hline Uzbekistan & 150 & 163 & 124 & Iran & 62 & 62 & 47 \\
\hline Georgia & 117 & 83 & 92 & Uzbekistan & 77 & 30 & 36 \\
\hline China & 47 & 31 & 59 & Georgia & 68 & 47 & 27 \\
\hline Israel & 29 & 52 & 40 & Azerbaijan & 22 & 22 & 20 \\
\hline Kazakhstan & 52 & 61 & 36 & Belarus & 9 & 13 & 14 \\
\hline Other countries & 515 & 693 & 662 & Other countries & 211 & 238 & 292 \\
\hline
\end{tabular}

Source: constructed using the resource:

https:/dmsu.qov.ua/divalnist/statistichni-dani/statistika-z-osnovnoi- diyalnosti.html 
A wide range of conditions and a slow multi-level procedure for reviewing documents by government agencies creates a system of certain filters for foreigners who are not of Ukrainian origin, but still seek to obtain Ukrainian citizenship. For example, only 3,739 people have been granted citizenship in the last four years. Most of them are foreigners from Syria, the Russian Federation, Armenia, Afghanistan and Moldova.

The following changes are necessary to overcome these bureaucratic barriers: the development of an electronic queue system for foreigners, the introduction of a service to check the status of the document, such as what will apply to biometric documents of Ukrainian citizens, increasing the number of inspectors working in the State Migration Service of Ukraine (SMS), who accept documents in accordance with the request for documents for foreigners, as well as the introduction of services for foreigners in the Centers for Administrative Services (CAS), creating a list of states whose legislation provides automatic loss of citizenship by persons who has acquired the citizenship of another state. Moreover, it is important to consider systemic issues, in particular the policy of language integration of foreigners, as well as the policy of dual citizenship.

Making the decision on the forced return of a foreigner or stateless person is within the competence of the State Migration Service of Ukraine, the State Border Service (regarding foreigners and stateless persons detained by them within controlled border areas while attempting to cross or after crossing illegally the state border of Ukraine) and authorities Security Services of Ukraine. The decision on the forced return indicates the period during which the foreigner or stateless person must leave Ukraine. The specified period shall not exceed 30 days from the date of the decision. It is important to note that the decision on the forced return of foreigners and stateless persons may be accompanied by a ban on further entry into Ukraine for a period of three years, which is calculated from the date of such a decision (Law of Ukraine No. 3773-VI, 2011).

Thus, according to the analysis of the current Ukrainian legislation, it should be noted that foreigners and stateless persons who have committed a crime, administrative or other offenses are liable in accordance with the law. For committing a crime defined by CCU norms, such persons are criminally liable and for committing administrative offenses they are brought to administrative liability. Foreigners and stateless persons may also face civil liability for obligations arising from harm (Hula I.L. (2018)).

\section{Discussion}

According to the results of the study, special attention should be paid to the issues of administrative liability of foreigners and stateless persons. Given the rule of Article 16 of CUAO, administrative penalties are applied to foreigners and stateless persons as defined in part 1 of Article 24, including a warning, a fine, etc. In addition to the indicated general sanctions, the current legislation of Ukraine also provides for the application of special (special) sanctions against foreigners and stateless persons, which include forced expulsion and forced return.

In the CUAO, administrative expulsion refers to administrative expulsion, which may be prescribed by law in the case of administrative offenses that grossly violate the rule of law. This provision is specified in Law No. 3773-VI, which provides for the use of forced expulsion of foreigners and stateless persons in the presence of an administrative offense, which grossly violates the rule of law. Additionally, Law No. 3773-VI establishes another special sanction in the form of the forced return of foreigners and stateless persons. At the same time, in the Instructions on the forced return and forced expulsion of foreigners and stateless persons from Ukraine, the terms "forced return" and "forced expulsion" mean a system of administrative and legal measures aimed at forcing foreigners who stay illegally in Ukraine to leave Ukraine despite their will and desire.

The administrative expulsion is classified as administrative sanctions in the CUAO because it is defined in Article 24 "Types of administrative penalties." At the same time, the forced expulsion and forced return of foreigners and stateless persons is defined as a system of administrative and legal measures in the Instructions on the forced return and forced expulsion from Ukraine of foreigners and stateless persons.

Thus, the problematic issues that should be addressed are the following ones. Firstly, the differences between 
the CUAO norms and the Instructions: in the CUAO, the forced expulsion is classified as penalties, in the Instructions, the forced expulsion at the level of forced return is an administrative and legal measure. Secondly, if the forced expulsion is classified as the administrative sanction in the CUAO, then there is a need for a rule that determines the composition of the offense, as a result of which a foreigner or stateless person will be forcibly expulsed. The solution of problematic issues is possible by bringing the norms of the Instructions on the forced return and forced expulsion from Ukraine of foreigners and stateless persons to compliance with the requirements of the CUAO, as well as predicting the norms in the CUAO, which determine the composition of the offense, upon the occurrence of which administrative (forced) expulsion will be applied. It should also be emphasized that the design of "administrative expulsion" is used in the CUAO, which is called "forced expulsion" in Law No. 3773-VI. It is more advisable to use the same definition in order to avoid doubts about the content of such concepts.

\section{Conclusions}

Effective management of social risks determines their consideration as complex objective-subjective phenomena characterized by uncertainty, ambiguity and diversity. The study of unemployment social risks using a managerial approach made it possible to identify certain positive consequences of their implementation, in particular for the development of the private sector and the introduction of special innovations. The main areas of managerial influence, aimed at reducing the likelihood of negative social consequences due to the actualization of social risks in the labor sphere, were identified as follows: management through direct influence on the causes of risks; management through the impact on causation; combining these two approaches.

The increase in labor migration from Ukraine is gradually exacerbating the imbalance prevailing in the Ukrainian labor market. Simplifying employment process and immigration conditions for foreign workers is one possible solution to this problem. Over the past five years, a number of measures have been taken in Ukraine in order to facilitate the application procedures for temporary and permanent residence permits and to simplify the employment process for foreigners.

Procedures for acquiring citizenship and obtaining permits for foreigners must be consistent with the principles of respect for human rights and non-discrimination. However, on the other hand, they demonstrate the existence of procedural shortcomings that create certain barriers and additional filters for persons who comply with the laws of Ukraine and want to obtain temporary and permanent residence permits, and subsequently acquire Ukrainian citizenship. Problems such as the complexity of supporting documents, queues and shortcomings in communication with relevant authorities need to be solved in order to develop a foreign-friendly immigration policy.

Creating conditions for the comprehensive integration of foreigners is an integral part of migration policy. A comprehensive assessment of integration policy according to the international MIPEX methodology (Migrant Integration Policy Index) has never been conducted in Ukraine, which in turn makes it difficult to compare Ukrainian integration policy with the relevant policies of EU member states. The results of the study indicate the existence of the language integration problem of foreigners, but it is equally important to conduct a comprehensive assessment of migrants' access to the Ukrainian labor market, education, health, participation in political life according to MIPEX methodology, which in turn will allow to adopt the best practices of integration from the EU member states.

In the case of an administrative offense, in accordance with the provisions of the Code of Administrative Offenses, administrative sanctions are applied to foreigners and stateless persons, as defined in Part 1 of Article 24 , including a warning, a fine, etc. In addition to the indicated general sanctions, the current legislation of Ukraine also provides for the application of special sanctions to foreigners and stateless persons, including: administrative expulsion; forced return; reduction of the period of temporary stay in Ukraine. It is important to pay attention to the difference between the forced expulsion and the forced return: firstly, the ground for the forced expulsion is an administrative misconduct that grossly violates the rule of law; secondly, for the appli- 
cation of forced expulsion of a foreigner or stateless person by authorized bodies (State Migration Service of Ukraine, State Border Service and bodies of the Security Service of Ukraine), an administrative court order on forced expulsion is required; thirdly, in the case of forced expulsion, the ban on the continued entry of foreigners and stateless persons into Ukraine for a period of five years.

With regard to criminal liability, the basis for bringing to this type of legal liability is the commission by a person of a socially dangerous act containing the offense provided for by the Criminal Code of Ukraine. Foreigners and stateless persons are held criminally liable on a common basis. At the same time, there are rules that criminalize foreigners and stateless persons as special entities for espionage, for violation of the laws on the continental shelf of Ukraine.

The extension in matters of liability of the national regime to foreigners and stateless persons does not preclude the onset of civil liability in civil claims filed against them. Civil liability for foreigners and stateless persons occurs for obligations arising from harm.

\section{References}

Association Agreement between Ukraine, of the one part, and the European Union, the European Atomic Energy Community, and their Member States, of the other part (2014). As amended up to Act of November 30, 2015. URL: https://zakon.rada.gov.ua/laws/show/ ru/984_011

Chehabeddine, M., Tvaronavičienė, M. 2020. Securing regional development. Insights into Regional Development, $2(1)$, 430-442. http://doi.org/10.9770/IRD.2020.2.1(3)

Code of Ukraine on Administrative Offenses (1984). As amended up to Act of March 18, 2020. URL: https://zakon.rada.gov.ua/laws/ show/80731-10

Constitution of Ukraine (1996). As amended up to Act of January 01, 2020. URL: https://zakon.rada.gov.ua/laws/show/254\%D0\%BA/96$\% \mathrm{D} 0 \% \mathrm{~B} 2 \% \mathrm{D} 1 \% 80$

Convention on the Reduction of Statelessness (1961). URL: https:/www.unhcr.org/ibelong/wp-content/uploads/1961-Convention-onthe-reduction-of-Statelessness ENG.pdf

Convention Relating to the Status of Stateless Persons (1954). URL: https://www.unhcr.org/ibelong/wp-content/uploads/1954-Convention-relating-to-the-Status-of-Stateless-Persons_ENG.pdf

Eurostat Database. URL: http://ec.europa.eu/eurostat/web/population-demography-migration-projections

Hrabylnikov, A.V. (2015). Constitutional legal status and legal regime of foreigners and stateless persons in Ukraine: correlation of concepts. Aktualni problemy vitchyznianoi yurysprudentsii, 6, 59-66.

Hula I.L. (2018). Personal expression from Ukraine of foreigners and universal membersas a west of administrative approach. Porivnialno-analitychne pravo, 4, 252-255.

Law of Ukraine № 3773-VI On the Legal Status of Foreigners and Stateless Persons (2011). As amended up to Act of February $13,2020$. URL: https://zakon.rada.gov.ua/laws/show/3773-17

Levenets, A.V. (2017). Municipal legal status of foreigners in Ukraine. The thesis for the degree of candidate of legal sciences, specialty 12.00.02. Karazin Kharkiv National University, Kharkiv. URL: http://dspace.univer.kharkov.ua/bitstream/123456789/12602/6/ diss-Levenec.pdf

Lincényi, M., Č́ársky, J. 2020. Policy trusts in public policy in the Slovak Republic. Insights into Regional Development, 2(1), 456-468. http://doi.org/10.9770/IRD.2020.2.1(5)

Plèta, T., Tvaronavičienė, M., Della Casa, S. 2020. Cyber effect and security management aspects in critical energy infrastructures. Insights into Regional Development, 2(2), 538-548. https://doi.org/10.9770/IRD.2020.2.2(3)

Reznik, O., Muzychuk, O., Andriichenko, N., Yakushchenko, Y., \& Korzh, S. (2020). Fight Against Doping: Experience of Ukraine and European States. Amazonia Investiga, 9(27), 34-41. https://doi.org/10.34069/AI/2020.27.03.4

State Migration Service of Ukraine. URL: https://dmsu.qov.ua/divalnist/statistichni-dani/statistika-z-osnovnoi-diyalnosti.html 
Statelessness in the EU (2016). EMN INFORM. URL: https://ec.europa.eu/home-affairs/sites/homeaffairs/files/00_inform_statelessness_final_en.pdf

Turetska, Y. (2018). Theoretical and practical aspects of the constitutional and legal status of refugees in Ukraine. Visegrad Journal on Human Rights, 2, 126-131.

Tvaronavičienė, M., \& Ślusarczyk, B. (2019). Energy transformation towards sustainability. Energy transformation towards sustainability (pp. 1-333) http://doi.org/10.1016/C2018-0-02510-4 Retrieved from www.scopus.com

Tymchyk G.S. (2014). Administrative and legal status of foreigners and refugees in Ukraine: a comparative legalanalysis. Yurydychnyi naukovyi elektronnyi zhurnal, 2, 82-84.

Vasylchenko, O.P. (2014). Features of the legal status of foreigners and stateless persons while ensuring the principle of equality of rights and freedoms in Ukraine. Yevropeiski perspektyvy, 10, 23-28.

\section{Oleg REZNIK}

ORCID ID: orcid.org/0000-0003-4569-8863

Oleksandr MUZYCHUK

ORCID ID: orcid.org/0000-0001-8367-2504

Oleksandr YUNIN

ORCID ID: orcid.org/0000-0003-4846-2573

Svetlana KALIUZHNA

ORCID ID: orcid.org/0000-0003-3796-6960

Oleksandr DUBENKO

ORCID ID: orcid.org/0000-0002-0443-7168 